\title{
Article \\ Thermal Runaway and Fire Suppression Applications for Different Types of Lithium Ion Batteries
}

\author{
Cagri Un $1, *(1)$ and Kadir Aydın ${ }^{2}$ \\ 1 Automotive Engineering Department, Çukurova University, Adana 01330, Turkey \\ 2 Mechanical Engineering Department, Çukurova University, Adana 01330, Turkey; kdraydin@cu.edu.tr \\ * Correspondence: cagri_un@hotmail.com
}

Citation: Un, C.; Aydın, K. Thermal Runaway and Fire Suppression Applications for Different Types of Lithium Ion Batteries. Vehicles 2021, 3 , 480-497. https://doi.org/10.3390/ vehicles3030029

Academic Editor: Teresa Donateo

Received: 10 July 2021

Accepted: 2 August 2021

Published: 5 August 2021

Publisher's Note: MDPI stays neutral with regard to jurisdictional claims in published maps and institutional affiliations.

Copyright: (c) 2021 by the authors. Licensee MDPI, Basel, Switzerland. This article is an open access article distributed under the terms and conditions of the Creative Commons Attribution (CC BY) license (https:/ / creativecommons.org/licenses/by/ $4.0 /)$.

\begin{abstract}
With the improvement of lithium-ion battery (LIB) technology, safety is becoming increasingly urgent topic for battery electric vehicles (BEVs). Short circuits, overcharging, high temperatures and overheating can cause thermal runaway reactions and the release of the flammable electrolyte which makes fire suppression very difficult. This study focuses on the mechanism of thermal runaway and fire suppression applications of LIBs. In order to understand this, 10 experiments were carried out. The experiments were divided into as Exp. A and Exp. B. A manual water suppression system was used in Exp. A and an automatic boron-based suppression system (AUT-BOR) was used in Exp. $B$. LIBs were heated in a controlled manner with a heat source and the effects of thermal runaway and fire suppression were observed. In Exp. A, a large amount of water was required to extinguish the LIB fires. The holes and slits which formed in the LIB after a fire were useful for injecting water. A projectile effect of cylindrical cells was observed in Exp. A. The Exp. B results showed that AUT-BOR mitigates risks effectively and safely. Also, AUT-BOR provides an early fire warning system and spot cooling to prevent thermal runaway reactions while localizing and suppressing the fire. In Exp. B, fire detection and suppression occurred without any explosion.
\end{abstract}

Keywords: lithium-ion batteries; BEVs; thermal runaway; fire suppression; boron

\section{Introduction}

Developments in battery electric vehicle $(\mathrm{BEV})$ technology and the progress of the automotive industry have contributed enormously to the changing technological panorama. Nowadays, a race is on between different LIB technologies to seeking to become the leader in a variety of applications. Ultimately, those applications and the fit between BEV technology and the requirements demanded by that application that will determine the winner of this race [1].

Commercially used LIB cells can be divided based on their structure and appearance into cylindrical and prismatic cells. Cylindrical cells are hard-case cells, while prismatic cells can either be hard-case rectangular prisms or so-called pouch cells with a soft, bag-like structure. Features of the production process of different kinds of LIB cells with a focus on the efficiency of the production cycle have shown that limitations of pick-and-place installation are described as the main bottleneck in the automotive sector [2].

Figure 1 shows the different commercially available cell types and their designs. A lithium-ion cell contains a cathode, an anode, separator and electrolyte. The anode and cathode materials are deposited onto copper and aluminum foil current collectors, respectively. The electrolyte facilitates the action of lithium ions between the electrodes, while the separator fits between the anode and cathode to avoid shorting between the two electrodes but allowing ion transfer. During the discharge phase, lithium ions move from the anode and insert into the voids between layers of cathode crystals (a process known as intercalation). Upon charging, lithium-ions move from the cathode on the positive side of the battery and insert into the anode [3]. 
Cylindrical

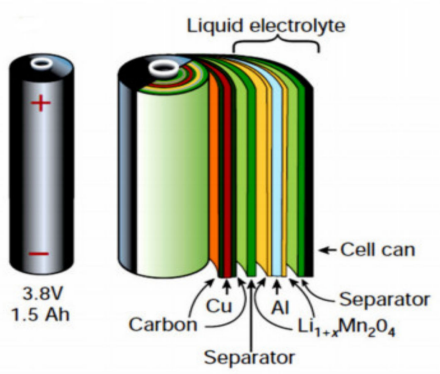

Button

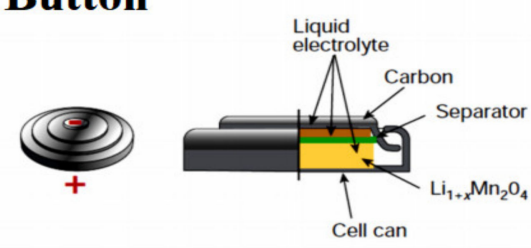

Prismatic
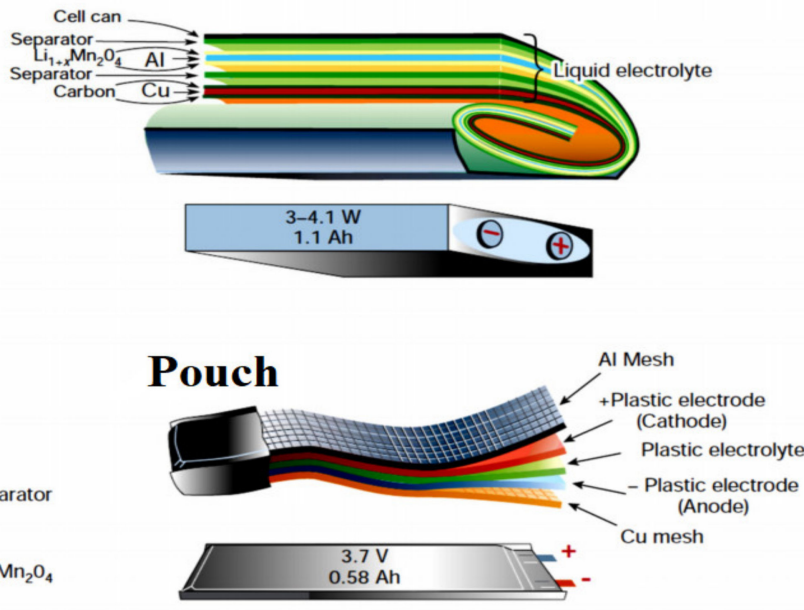

Figure 1. Different commercially available cell types [4].

The LIBs' components and reactions are shown in Figure 2. The principle of the LIB shows the intercalation of lithium-ions (yellow spheres) into the anode and cathode matrices upon charge and discharge, respectively.

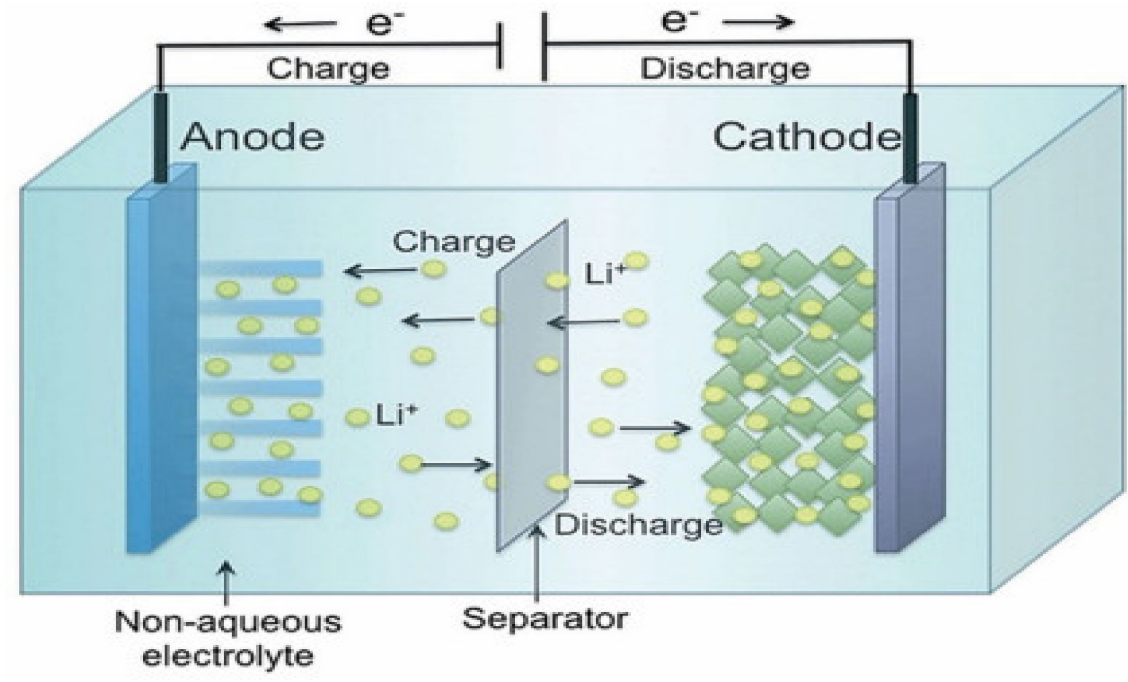

Figure 2. The LIBs components and reactions [5].

In order to create high-power batteries for BEVs, lots of lithium-ion cells will be required. On the other hand, safety situations remain an important concern, as battery failure leads to the ejection of hazardous materials and quick heat release [6].

\section{Thermal Runaway Reactions}

BEV fires can occur due to battery failure. The most common mode failure of LIB is the thermal runaway reaction. Thermal runaway reactions are a widely observed phenomenon in combustion reactions, referring to an overheating event in which exothermic chain reactions take place and overcome the available cooling. For the LIB, thermal runaway usually means an increase in battery temperature (more than $10^{\circ} \mathrm{C} / \mathrm{min}$.) or the activation of a safety vent, which indicates that exothermic thermochemical and electrochemical reactions have been initiated. Thermal runaways are usually accompanied by the ejection 
of a large amount of dark smoke, hot sparks and flames. As this reaction takes place within the individual cells, its risk potential increases when the propagation of the thermal runaway or fire throughout a lithium-ion battery is allowed to proceed [7].

A thermal runaway is a rapid internal temperature increase that often results in one or more of the following events: heat generation, gas and smoke formation, cell breach/cell explosion, fire or gas explosion. Gas releases can typically occur at lower temperatures and without the occurrence of a thermal runaway.

In spite of the wide usage of LIBs in energy storage applications, LIBs are sensitive to thermal runaway and combustion which is the primary safety concern when used in HEVs, BEVs, airplanes and submarines [8,9]. The LIB systems used in these applications consist of multi cell packs and modules where thermal runaway in a single cell can initiate thermal runaway in contiguous cells and as a result compromise the integrity of the entire battery system $[10,11]$.

When LIBs fail due to short circuits, overcharging, high temperatures, mechanical damage and overheating, this might cause a thermal runaway reaction. A thermal runaway occurs when a cell has reached the temperature at which it will continue to increase on its own, and the electrolyte catches fire. These fires can develop quickly. The release of flammable electrolyte makes fire extinguishing very difficult and in addition there a lot of toxic gases are usually emitted, such as hydrogen fluoride, which can cause serious damage to both the skin and the respiratory tract [12].

Thermal runaway results from an increasing cell temperature because of either external heating or internal heat generation within the cell. If the temperature continues to increase, the electrolyte will boil, causing an increase in pressure within the cell [13].

If the pressure reaches a critical point, the cell can rupture, releasing flammable gases and in some examples; projectiles at high speeds [14]. These gases have the potential to combine with oxygen in the air and form an explosive mixture. Mechanical failures include physical damage, an internal short circuit or a production defect. Other conditions such as low ambient pressure, vibration, shock, corrosion or impact can also start a mechanical failure event within a LIB [15].

The conditions which may lead to thermal runaway and fire in LIBs can be divided into four categories [16]:

$\checkmark \quad$ Electrical abuse: Over-charging or discharging to voltages beyond the manufacturer's specified charge window can cause lithium plating, or dendrite formation, on the anode. Over time, this may pierce the separator, causing a short circuit between electrodes and lead to thermal runaway.

$\checkmark$ Thermal abuse: An internal temperature in the $90-120{ }^{\circ} \mathrm{C}$ range will cause the solid electrolyte interphase layer within a LIB to decompose exothermally. At temperatures above $200{ }^{\circ} \mathrm{C}$, the hydrocarbon electrolyte can decompose and release heat.

$\checkmark$ Mechanical abuse: Mechanical abuse, usually caused by external setback to the LIB such as crash or during installation, can result in electrical shorting between the electrodes, with the electrolyte, producing localized heating.

$\checkmark$ Internal short circuit: An internal short circuit occurs because of the failure of the separator, allowing contact between the cathode and anode via the electrolyte. This can happen due to any of the above abuse conditions or as a result of a production fault.

Potential causes of the LIB accidents and mechanisms leading to the separator tearing, piercing and collapsing, subsequently internal short circuit, and possibly thermal runaway are presented in Figure 3 [17]. 


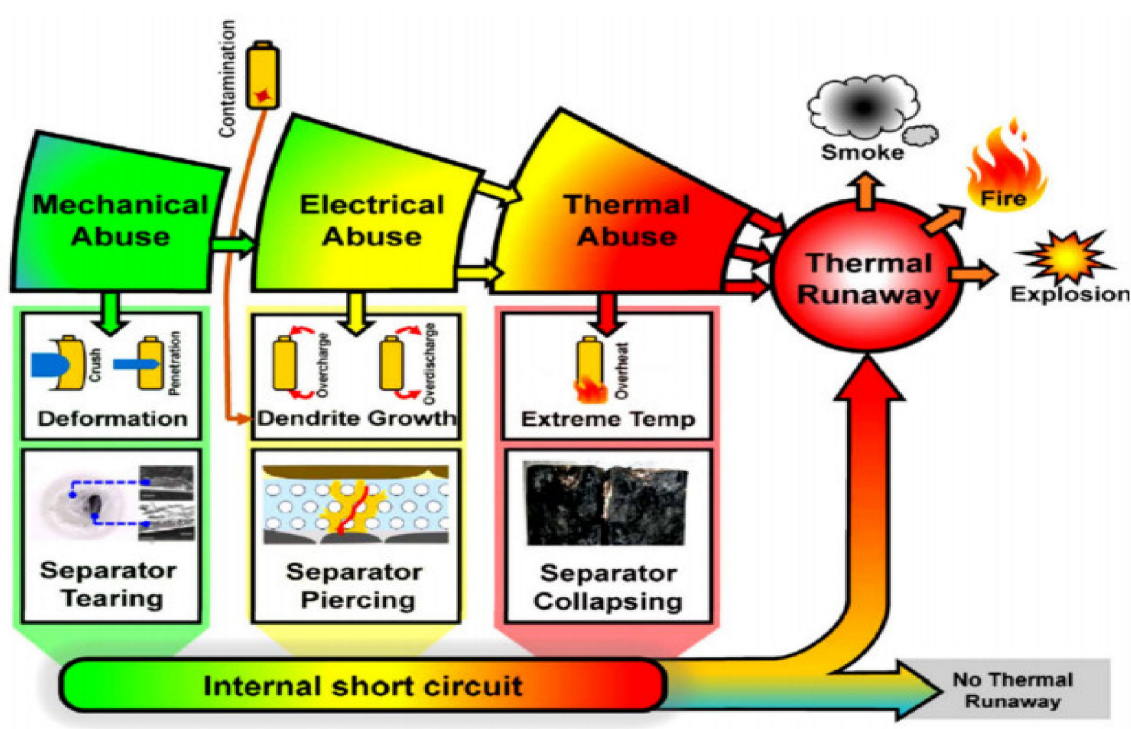

Figure 3. Various abuse conditions of thermal runaway and fire.

As more electric vehicles become operational, their involvement in fire incidents is likely to rise. Fires in LIBs can progress rapidly and become difficult to suppress, making it critical to control and eliminate such threats in advance. The outcome from a defective LIB can be very serious, potentially resulting in a thermal runaway situation with rapid fire and heat propagation as well as emission of toxic gases, posing a great threat to drivers and passengers.

For BEVs and HEVs, potential fire sources are often located in different sections of the vehicle. This means that more protection zones will have to be taken into account. Furthermore, a combination of different extinguishing methods will have to be used due to the different types of fires that might occur, as well as the sensitivity of electrical components [12].

The growth of BEV industry has accelerated the demand of new fire suppression technologies. The extinguishing steps of LIB fires can be summarized as follows: detect potential battery failure as early as possible and to take immediate action to stop a potentially hazardous situation.

In this work a manual water suppression system and an automatic boron-based suppression system (AUT-BOR) were investigated. Boron-based automatic fire suppression systems, which have emerged as a new fire extinguishing product, are considered a highly innovative fire protection system for LIBs.

Commonly found in the Earth's crust, boron happens to be the 51st element of the periodic table and is not found in Nature in its elemental state. It is known that there are about 230 different boron minerals in Nature. Turkey has the largest boron reserves in the world. In addition to this, Turkey's boron minerals have the highest quality and production conditions that are more economical than other boron-producing countries. For this reason, boron has great importance for Turkey and there is a significant demand for new areas of usage, so that Turkey would be able to contribute to the national economy with these resources [18]. Boron has many uses. Among these, its fire suppression features, which have emerged as a new area of usage, as a result of studies in recent years, is also an important subject of this research.

\section{Materials and Methods}

In this study, two different experimental setups were established, identified as Exp. A and Exp. B, respectively. Also in this study, different types of cells and LIBs were heated with propane gas burners and any fires observed in these cells and batteries were suppressed with water and boron-based liquid fire extinguishers. The thermal runaway 
situations of the different types of cells and LIBs and their extinction with a manual water suppression system (Exp. A) and boron-based liquid fire suppressant (Exp. B) were observed. Exp. A experiments were conducted at the University of Poitiers, The National School of Mechanics and Aerotechnics (ISAE-ENSMA) and the The Prime Institute Academicians (in the city of Poitiers in France) with the help of Departmental Fire and Rescue Service of Vienne Regional officers. Exp. B experiments were conducted at Çukurova University with Departmental Fire and Rescue Service of Adana Metropolitan Municipality officers.

Cells and LIBs used in Exp. A and Exp. B were selected from the models currently used in buses and the electric vehicles industry. In order to detect the thermal runaway and suppression effect on different cell and battery models a variety of models were chosen. The cells and batteries were supplied by manufacturers providing services in the sector. These manufacturers target a series of market segments comprising light electric vehicles, commercial vehicles, buses, industrial vehicles, railway vehicles and ships. The characteristics of cells and LIBs, used in the experiments within the scope of this study, are given below.

\subsection{Exp. A Experiments}

The lithium-ion cells and batteries used in Exp. A are described in Table 1.

Table 1. Technical characteristics of the cells and LIBs used in Exp. A.

\begin{tabular}{|c|c|c|c|c|c|}
\hline Product Name & $\begin{array}{c}\text { Volume of } \\
\text { Electrolyte per } \\
\text { Cell }\end{array}$ & $\begin{array}{l}\text { Number of the } \\
\text { Cells per } \\
\text { Module/Pack }\end{array}$ & $\begin{array}{l}\text { Weight of the per } \\
\text { Module/Pack (kg) }\end{array}$ & $\begin{array}{c}\text { The Weight of } \\
\text { System/String (kg) }\end{array}$ & $\begin{array}{l}\text { Average Thermal } \\
\text { Runaway } \\
\text { Temperature }\left({ }^{\circ} \mathrm{C}\right)\end{array}$ \\
\hline NMC-a (Pouch) & $10-30 \%$ of weight & $20 /$ module & 28 & $1232^{\mathrm{a}}$ & \\
\hline NMC-b (Pouch) & $10-30 \%$ of weight & $176 /$ pack & $280( \pm 5)$ & $2800^{b}$ & $200^{\circ} \mathrm{C}$ \\
\hline NMC-c (Pouch) & $10-30 \%$ of weight & $48 /$ module & $81-83$ & $2268-2324^{c}$ & \\
\hline LTO (Prismatic) & $5-15 \%$ of weight & 276/pack & $260( \pm 5)$ & $2080^{d}$ & $250^{\circ} \mathrm{C}$ \\
\hline NCA (Cylindrical) & $5-10 \%$ of weight & $260 /$ pack & 13 & 13 & $150^{\circ} \mathrm{C}$ \\
\hline LFP (Cylindrical) & $5-10 \%$ of weight & 400/pack & 20 & 20 & $195^{\circ} \mathrm{C}$ \\
\hline
\end{tabular}

${ }^{\mathrm{a}} 1$ string $=4$ packs $(44 \text { modules })^{\mathrm{b}} 1$ system of 10 strings $(1 \text { pack }=1 \text { string })^{\mathrm{c}} 1$ string of 28 modules ${ }^{\mathrm{d}} 1$ system of 8 modules.

LIBs are formed by connecting cells in series or parallel to each other. LIBs have cylindrical, prismatic and pouch type geometric features. In the automotive industry the energy system consists of many cells combined to provide the required voltage, power and energy. The cells are assembled into a series of modules, which then form the package and the system.

The NMC-a (Pouch), NMC-b (Pouch), NMC-c (Pouch) and LTO (Prismatic) lithium-ion cells used in Exp. A are shown in Figure 4.

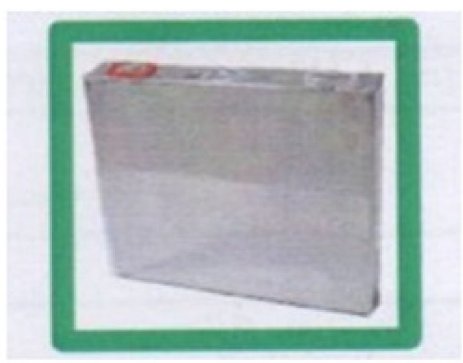

(a)

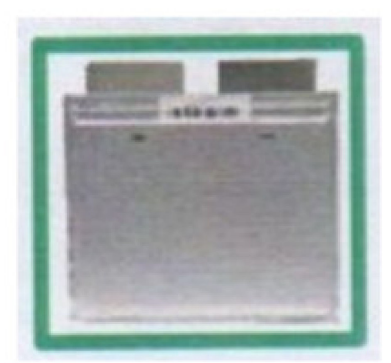

(b)

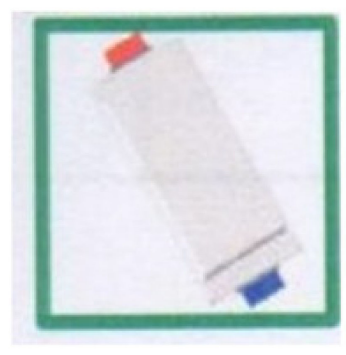

(c)

Figure 4. (a) LTO (Prismatic) (b) NMC-c (Pouch) (c) NMC-a (Pouch) and NMC-b (Pouch).

The installation shapes of the LIBs are used as modules and packages in the Exp. A experiments are shown in the figures below (Figures 5-8). As can be seen in the figures, 
there is a high risk of thermal runaway in batteries that are connected in series with each other. This highlights the importance of rapid detection and intervention.

NMC-a (Pouch) cell

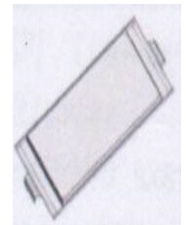

20 cells $=1$ Module

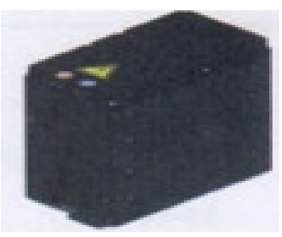

11 modules $=1$ Pack

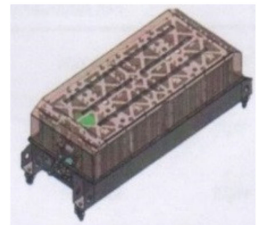

4 Packs $=1$ String

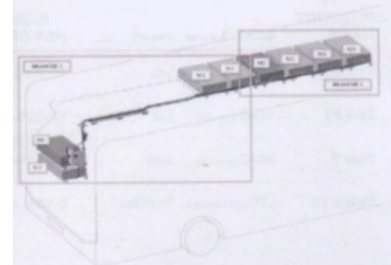

Figure 5. The installations of the NMC-a (pouch) type LIB.

NMC-b (Pouch) Cell

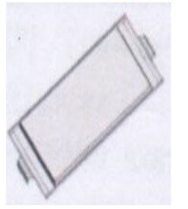

176 cells $=1$ Pack

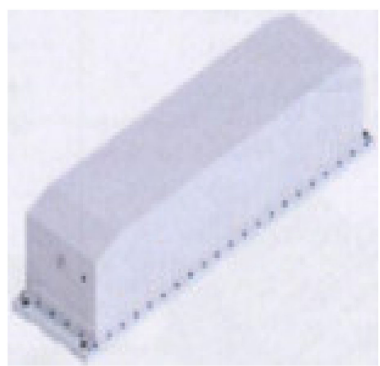

10 Packs Connected in Parallel $=1$ System

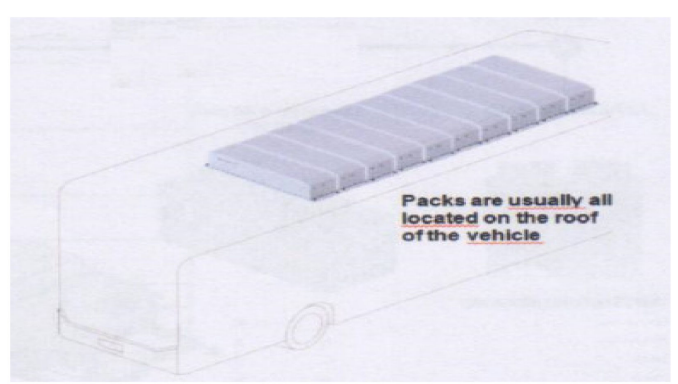

Figure 6. The installations of the NMC-b (pouch) type LIB.

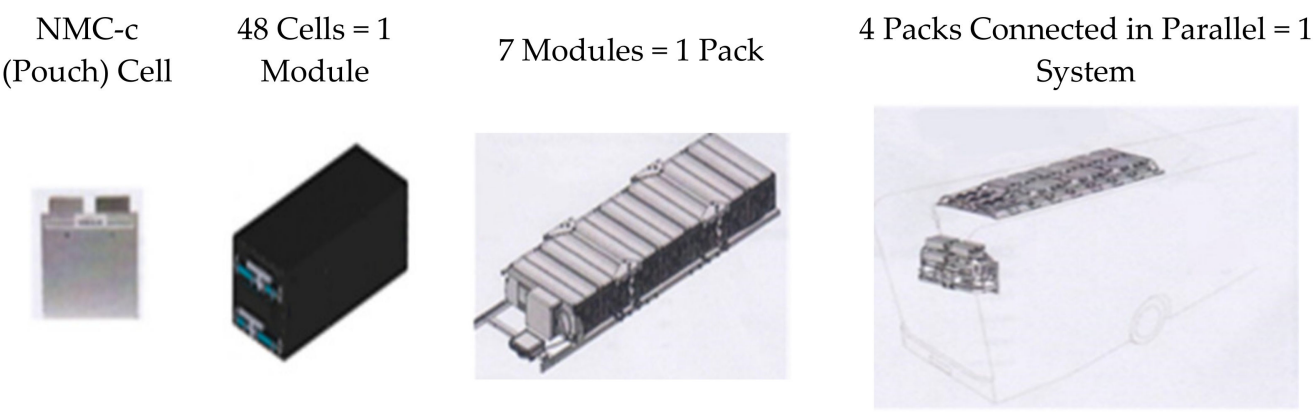

Figure 7. The installations of the NMC-c (pouch) type LIB.

LTO (Prismatic) cell

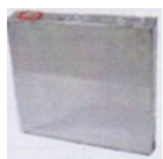

276 Cells $=1$ Pack

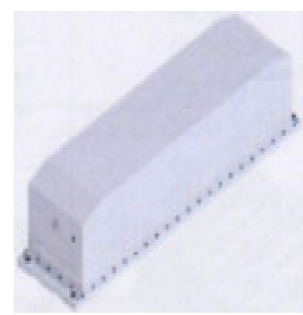

8 Packs Connected in Parallel $=1$ System

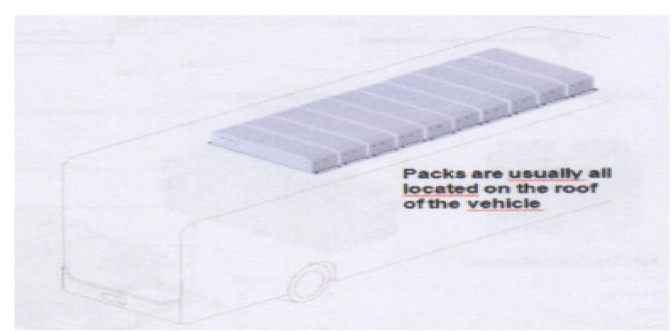

Figure 8. The installations of the LTO (prismatic) type LIB.

The physical features of the modules and packages, which are composed of cells used in Exp. A experiments, are also given in Figure 9. 


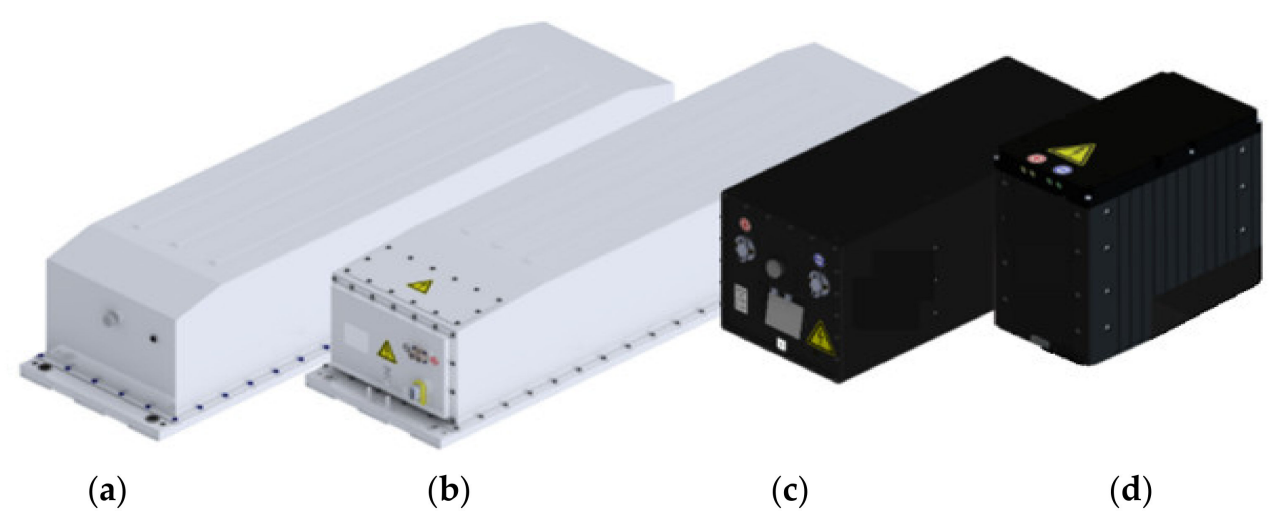

Figure 9. (a) NMC-b/Pouch type $/ 280 \mathrm{~kg} / 32 \times 44 \times 170 \mathrm{~cm} /$ bottom of the pack: steel/perimeter of the pack: aluminum/1 pack, (b) LTO/Prismatic type $/ 260 \mathrm{~kg} / 32 \times 44 \times 170 \mathrm{~cm} /$ bottom of the pack: steel/perimeter of the pack: aluminum/1 pack, (c) NMC-c/Pouch type $/ 80 \mathrm{~kg} / 27 \times 28 \times 70 \mathrm{~cm} / \mathrm{base}$ of the module: plastic/perimeter of the module: aluminum/1 module, (d) NMC-a/Pouch type/ $28 \mathrm{~kg} / 30 \times 18 \times 33 \mathrm{~cm} /$ base of the module: plastic/perimeter of the module: aluminum/1 module.

The batteries in Figure 10, specified as (a) NCA/cylindrical type/13 kg/25 $\times 37$ $\times 18 \mathrm{~cm} /$ plastic package and (b) $\mathrm{LFP} /$ cylindrical type $/ 20 \mathrm{~kg} / 32 \times 25 \times 21 \mathrm{~cm}$./plastic package LIBs were also used in Exp. A experiments.

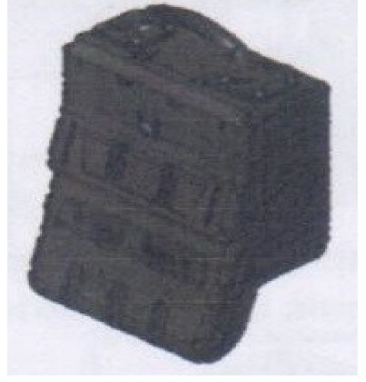

(a)

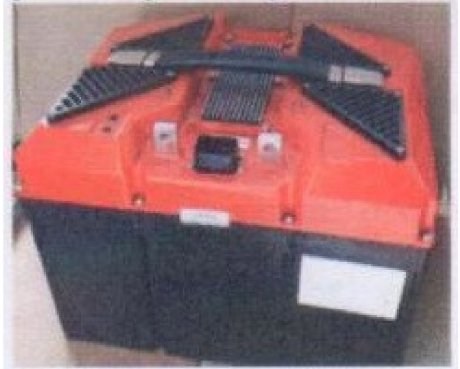

(b)

Figure 10. (a) NCA (Cylindrical) LIB, (b) LFP (Cylindrical) LIB.

The experiments were performed using an external propane burner for the purpose of heating and igniting the battery cells as described in the experiments. Ten $\mathrm{kW}$ and $400 \mathrm{~kW}$ propane $\left(\mathrm{C}_{3} \mathrm{H}_{8}\right)$ gas burners were placed underneath metallic tables, on which the cells and LIBs were placed and ignited (Figure 11).

The thermal runaway and fire issues of the different types of cells, batteries and their suppression with water suppressant were observed for Exp. A experiments. (Table 2). 


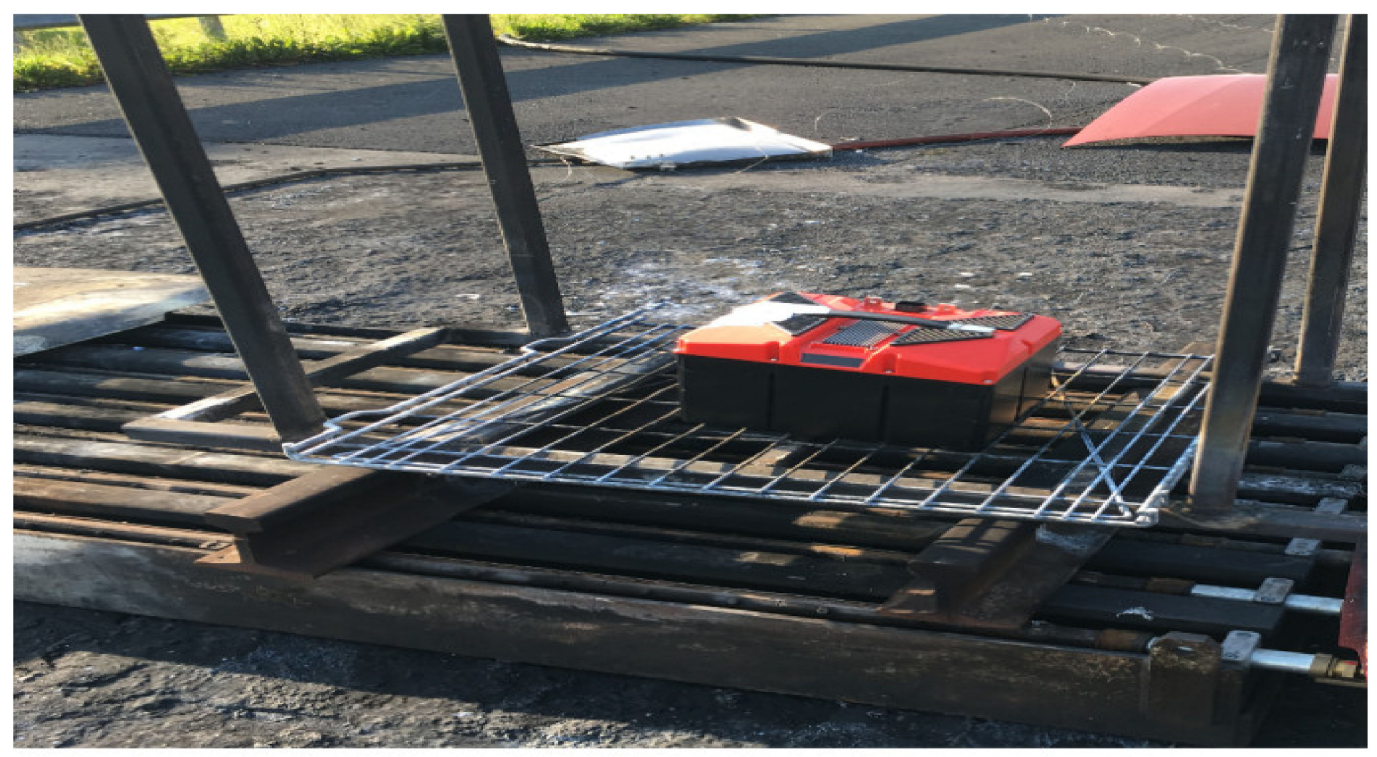

Figure 11. Propane gas burner $(400 \mathrm{~kW})$.

Table 2. Exp. A experimental details.

\begin{tabular}{|c|c|c|}
\hline $\begin{array}{c}\text { Experiment } \\
\text { Number }\end{array}$ & Materials & Objectives \\
\hline Exp. A.1 & NMC-b (Pouch), cell & Cells were exposed to heat source. The \\
\hline Exp. A.2 & NMC-a (Pouch), cell + LTO (Prismatic), cell & temperature increased during the thermal \\
\hline Exp. A.3 & LTO (Prismatic), cell & runaway. \\
\hline Exp. A.4 & NMC-a (Pouch) LIB in a package (aluminium and plastic case) & Water effect on module/pack Cobra type \\
\hline Exp. A.5 & NMC-c (Pouch) LIB in a package (steel case) & $\begin{array}{l}\text { water efrect on moaule/ pack. Cobra type } \\
\text { water-based extinguisher was used. }\end{array}$ \\
\hline Exp. A.6 & LTO (Prismatic) LIB & \\
\hline Exp. A.7 & NCA (Cylindrical) LIB with plastic case & $\begin{array}{l}\text { Water effect on the scooter module in } \\
\text { fire/examination of the reaction. }\end{array}$ \\
\hline Exp. A.8 & LFP (Cylindrical) LIB with plastic case & Cobra type water-based extinguisher was used. \\
\hline
\end{tabular}

\subsection{Automatic Boron-Based Liquid Fire Suppression System}

Known as traditional firefighting methods, water, synthetic or detergent-added foams are insufficient against fires reaching $700{ }^{\circ} \mathrm{C}$ in a short time. When the applications of the fire sector around the world are examined, it is seen that the purpose of fire intervention is to control the fire instead of extinguishing the fire quickly. Boron-based fire suppression compounds, which are non-carcinogenic, with a longer shelf life and solid cooling technology that is not found in conventional fire extinguishers, appear to be an innovative system that prevents the progression and reignition of a fire by forming a film layer in the area where it was applied with the principle of smothering the fire.

Boron is highly resistant to burning, because it is oxide and its melting temperature is $2300{ }^{\circ} \mathrm{C}$. Due to this feature, it is used as a fire retardant or it is added as substance with this feature in different proportions. In particular fire retardants like zinc borate, borax, or ammonium fluoroborate products are used together with antimony trioxide. These are superior products. These types of products prolong the absorption rate of smoke and quickly suppress fire in the form of embers.

The properties of the boron-based liquid type fire suppressant used in the trials within the scope of this project are given Table 3. This product is odorless, has a melting point below $600{ }^{\circ} \mathrm{C}$. This product also has water repellence properties. 
Table 3. Component properties of boron-based liquid fire suppressant [19].

\begin{tabular}{ccc}
\hline Component Name & CAS No & Concentration \\
\hline $\mathrm{Na}_{2} \mathrm{~B}_{4} \mathrm{O}_{7} 5 \mathrm{H}_{2} \mathrm{O}$ & $12179-04-3$ & $10-20 \%$ \\
$\mathrm{SiO}_{2}$ & $112926-00-8$ & $<1 \%$ \\
Sodium bicarbonate & $144-55-8$ & $15-30 \%$ \\
\hline
\end{tabular}

Borax pentahydrate is obtained from tincal $\left(\mathrm{Na}_{2} \mathrm{~B}_{4} \mathrm{O}_{7} \cdot 10 \mathrm{H}_{2} \mathrm{O}\right)$ ore in powder or crystal form. During the production phase dissolving, precipitation with various flocculants (anionic, etc.), centrifugation, filtration, crystallization and drying stages are applied [20]. In Exp. B; a newly developed boron-based liquid fire suppressant was tested. This product is a new product on the market against other fires. In this study, it was tried for the first time on LIBs.

\subsection{Exp. B Experiments}

In Exp. B experiments 18,650 LCO type, 3.7 V, 2000 milliampere hour (mAh) rechargeable lithium-ion batteries were used (Figure 12).
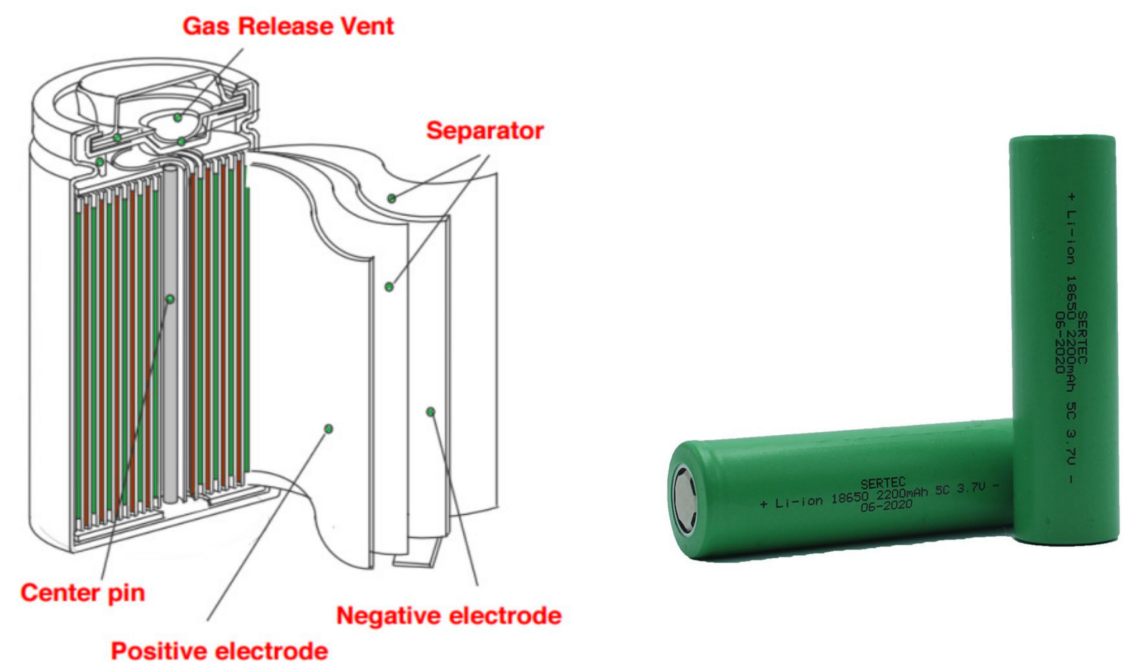

Figure 12. 18,650 LCO type lithium-ion battery used in Exp. B experiments.

The 18,650 LCO type lithium-ion battery has a cylindrical shape, $18 \mathrm{~mm}$ in diameter and $65 \mathrm{~mm}$ in length, and is widely used on the market. Due to its advantageous properties, the 18,650 battery produced for use in laptop computers has been adopted for use in various power devices, electric bicycles, portable applications and automotive applications (e.g., Tesla electric cars). Considering the lithium-ion batteries, the wide usage area of the 18,650 battery has made the studies with this battery interesting and increased [21].

In Exp. B experiments; 15 18,650 LCO type 2000 mAh LIB units were tightly bounded together by using metal wire to and placed on a $1.4 \mathrm{~kW}$ heating burner (Figure 13).

In the Exp. B. experiments, thermal runaway and fire suppression data have been recorded by the main control system. In Exp. B a flame detector system was used on the lithium-ion batteries (Figure 14b). Temperatures were monitored with PT-100 thermocouples. These thermocouples were placed on the exterior surfaces of the lithium-ion battery system. Flame detectors react to the radiation from the flames. They may be sensitive to infrared, ultraviolet radiation or both. The reason to complement the fire detection system with flame detectors is to get a very fast response in case of fast developing flaming fires, e.g., ignition of a ruptured fuel line [22]. 


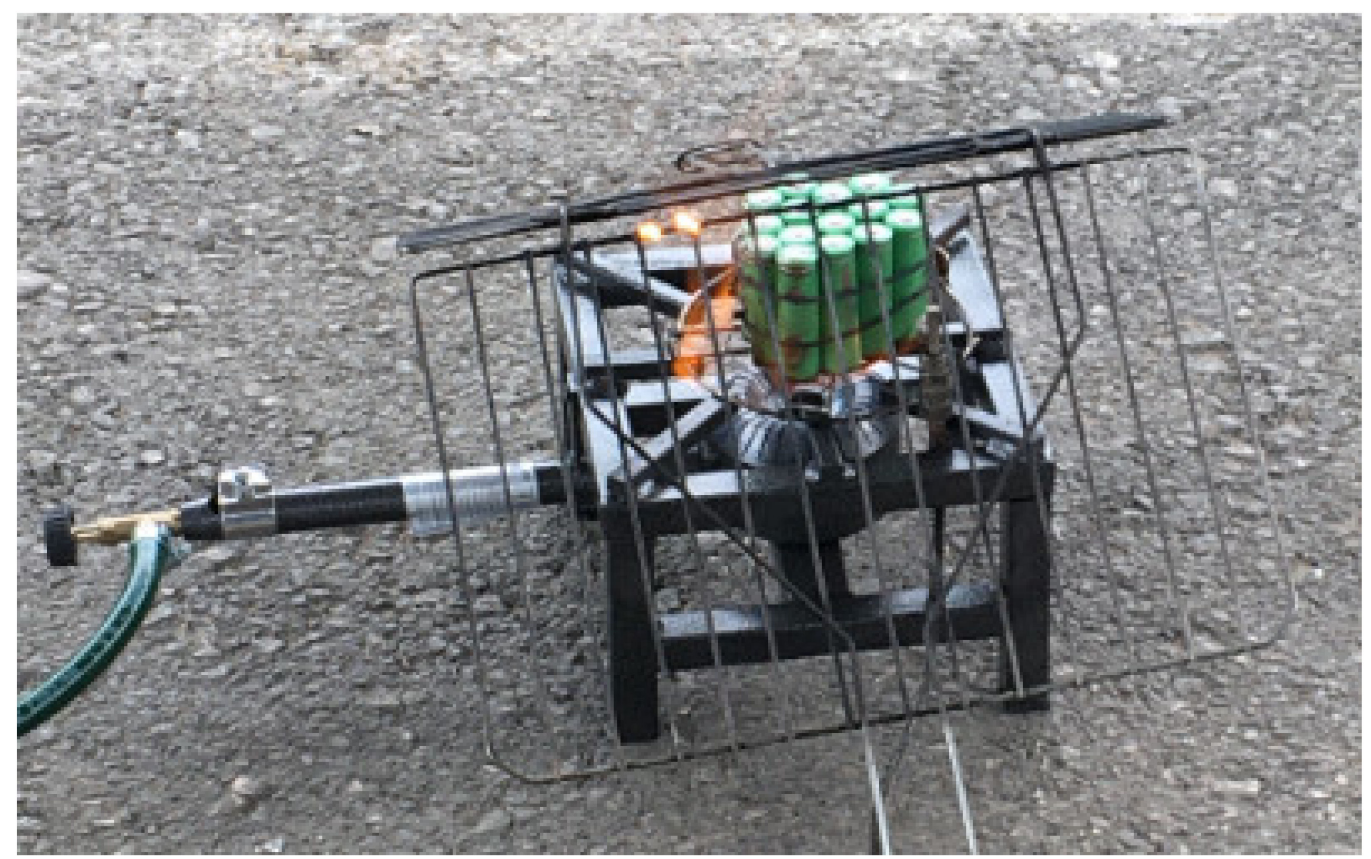

Figure 13. Exp. B experimental setup.

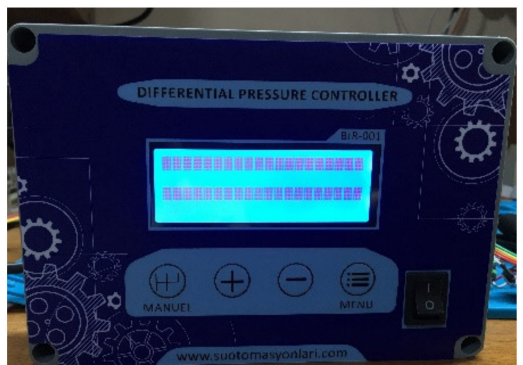

(a)

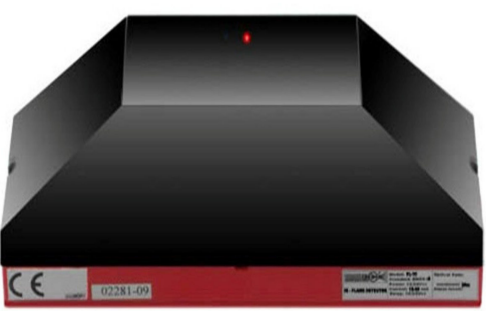

(b)

Figure 14. (a) Control panel, (b) Flame detector.

The nozzle and distribution control panel system status is constantly monitored by the control panel and communicated by visual LED indicators and an audible alarm. Fire detection was provided by fixed temperature thermostats and flame detector. Boron based fire suppression agent was delivered to hazard areas by fixed, high capacity, fast flow machined nozzle, allowing for fast and automatic vehicle fire suppression, crucial to saving both lives and machinery.

Two different experiments were conducted within the scope of Exp. B. Those were designated as Exp. B.1 and Exp. B.2. Exp. B.1 was to observe the thermal runaway of a 18,650 LCO type LIB. In Exp. B.1, only thermal runaway and fire situation were observed. No fire extinguisher was used. The results and effects of the thermal runaway were recorded. For Exp. B.2; a 18,650 LCO type lithium-ion battery was burned and the fire was extinguished by AUT-BOR.

For Exp. B.2; the process was established to test the thermal runaway of lithiumion batteries, controlled by a fire alarm and extinguishing panel, capable of cross-zone detection. With this system the activation was made with the principle of controlling the temperature increase. In the extinguishing zone within the detection zone, the system has been designed taking into account the flame and temperature that would occur in case of a possible fire risk. An 18 bar nitrogen gas system was used as pressurized gas in the fire extinguisher, and a total of $6 \mathrm{~kg}$ boron-based liquid extinguisher was placed in the fire extinguisher. A hose connection and solenoid valve were installed at the exit of the 
boron-based fire extinguisher, the liquid chemical was thus released. Thermal runaway reactions were detected with the dual control system which was set up for the Exp. B.2. The temperature measurement device was mounted on the battery on the heater and the temperature increase was recorded automatically. The fire, which was verified by the control system, was triggered to the boron-based fire extinguisher, which was connected to the extinguishing zone where the fire was detected, by means of a solenoid valve and the system extinguished the fire.

\section{Results and Discussion}

The thermal runaway of a LIB is a phenomenon that occurs when it is subjected to very high temperature conditions. A thermal runaway is a rapid internal temperature increase that often results in one or more of the following events: heat generation, gas and smoke formation, cell breach/cell explosion, fire or gas explosion. Gas releases can typically occur at lower temperatures and without the occurrence of a thermal runaway [21].

\subsection{Exp. A.1-8}

In the Exp. A.1 experiment an NMC-b (Pouch) cell was used. A rapidly progressing and intense combustion was observed (Figure 15). The LIB was placed on a small burner. The cell started to burn intensely $6 \mathrm{~s}$ after the ignition was started. Along with the combustion, gas output also occurred. The aluminum and plastic film packaging used in pouch type cells has certain flexibility. When a safety issue arises, the pouch cell battery swells and cracks, but does not explode.
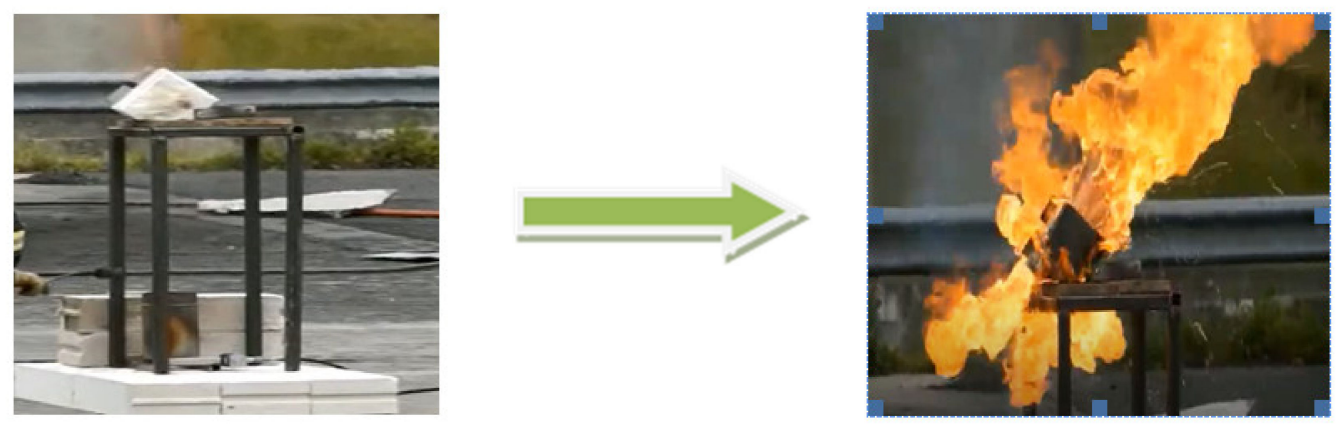

Figure 15. Exp. A.1 experiment.

In the Exp. A.2 experiment an NMC-a (Pouch) cell and an LTO (Prismatic) cell were put onto the small burner at the same time. The NMC-a (Pouch) cell showed a faster and more intense combustion compared with the LTO (Prismatic) cell. The NMC-a (Pouch) cell burned intensely and gassed out $7 \mathrm{~s}$ after the ignition was started. The LTO (Prismatic) cell did not gas out and burned at the same rate in the same period (Figure 16). The different responses of cells to combustion depends on the structural setup of the batteries.
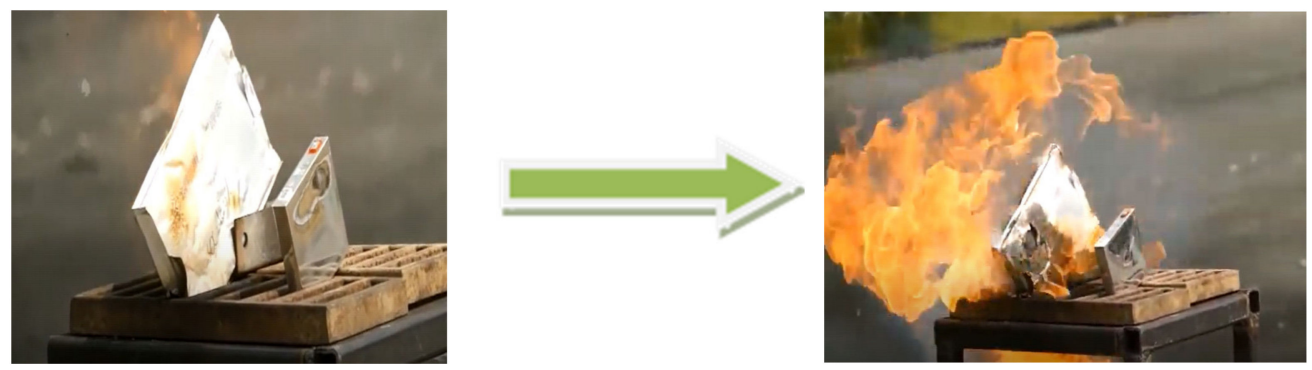

Figure 16. Exp. A.2 experiment. 
In the Exp. A.3 experiment, a LTO (Prismatic) cell was heated on a small-scale propane burner. It has been observed that LTO (Prismatic) cell burned less and was less affected by combustion than the other types (Figure 17) and also has good high temperature tolerance performance.
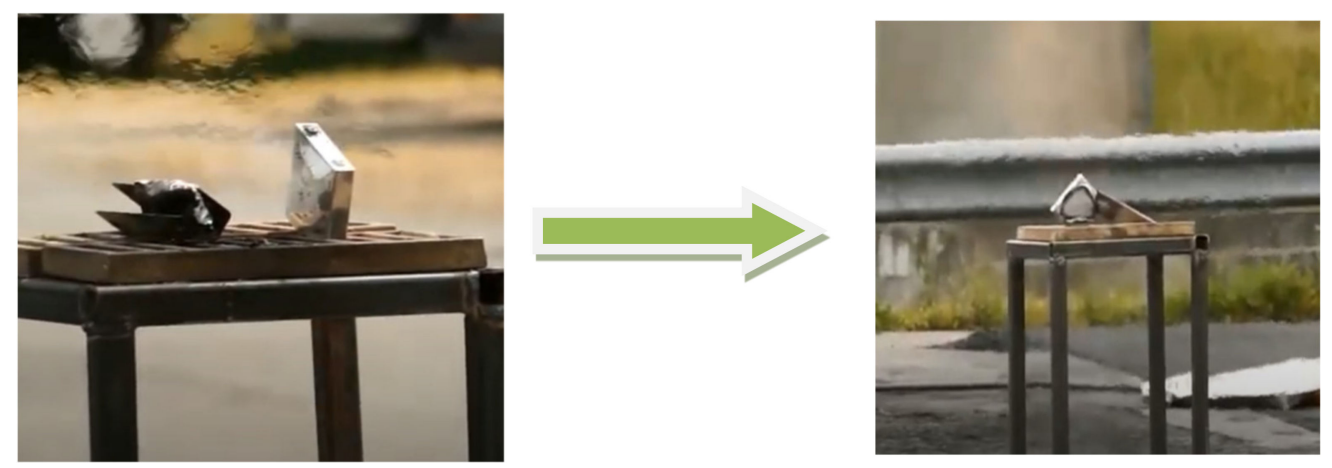

Figure 17. Exp. A.3 experiment.

In Exp. A.4 experiment an NMC-a (Pouch) LIB, which was surrounded by aluminum and a plastic bottom package, was used. Intensive burning was observed in this experiment. At the 6th minute of the onset of combustion; thermal runaway, gas outlet and explosions began to occur inside the LIB. At the 8th minute; suppression was started with the Cobra type water fire extinguishing system. Shortly after the beginning of the extinguishing activity, there was a dense smoke emission at the 9th minute (Figure 18). The extinguishing activity was stopped with the beginning of dense smoke. At the 11th minute of the beginning, the smoke output was over and the second extinguishing operation was carried out. When the NMC-a (Pouch) LIB was examined after the combustion was over, it was observed that the combustion had affected the inner parts (Figure 18).

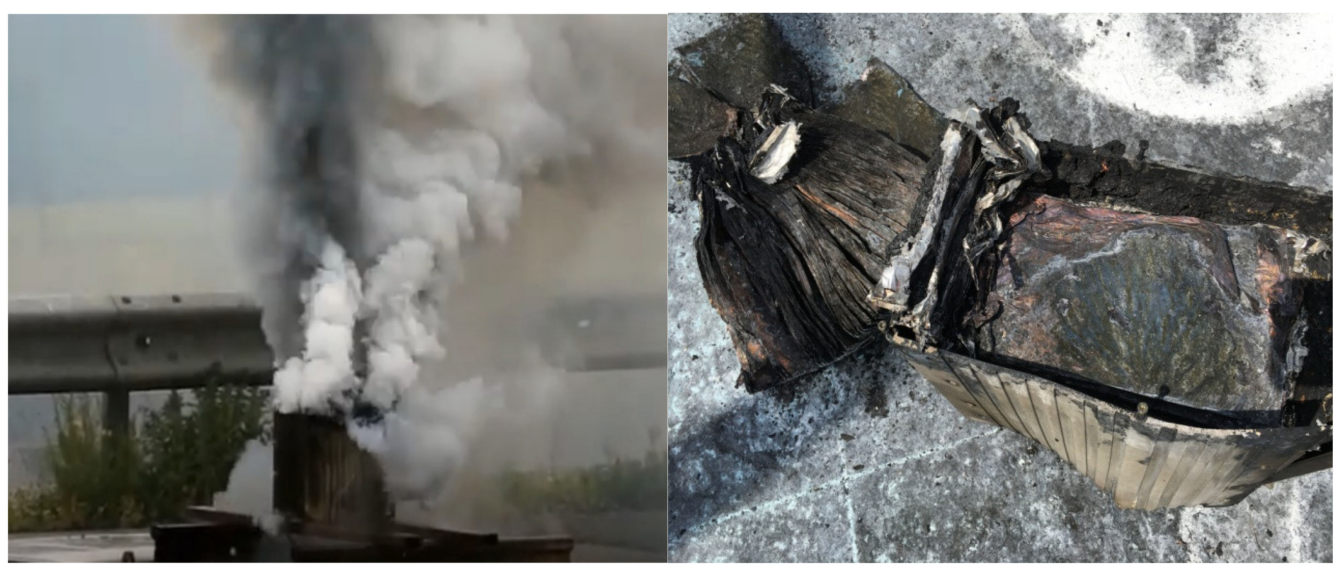

Figure 18. Exp. A.4 experiment.

To summarize, in Exp. A.4:

$\checkmark \quad$ It has been seen that the use of large amounts of water is necessary to suppress the NMC-a (Pouch) LIB fire

$\checkmark \quad$ There was a significant smoke output

$\checkmark \quad$ After the extinguishing activity a risk of re-burning has been observed.

In the Exp. A.5 experiment an NMC-c (Pouch), steel-lined pack LIB was used. A thermal runaway reaction occurred after the 22nd minute from the start of heating. Extinguishing was started with a Cobra type water fire extinguishing system at the 27th minute. In order to inject water into the lithium-ion battery; the holes, which formed on the battery surface, were used. These holes occurred due to the deformations in the aluminium 
structure with the increase of temperature. Smoke output was low (Figure 19). In the Exp. A.5 experiment; it was observed that the steel coating on the outer surface of the LIB, slowed down the formation of the thermal runaway. Conversely, the need of a high quantity of water was the same as for the flexible cell module in the steel coating, where the deformation of the pack or the melting of the fusible parts allowed water to be injected into the battery and therefore suppress the fire.

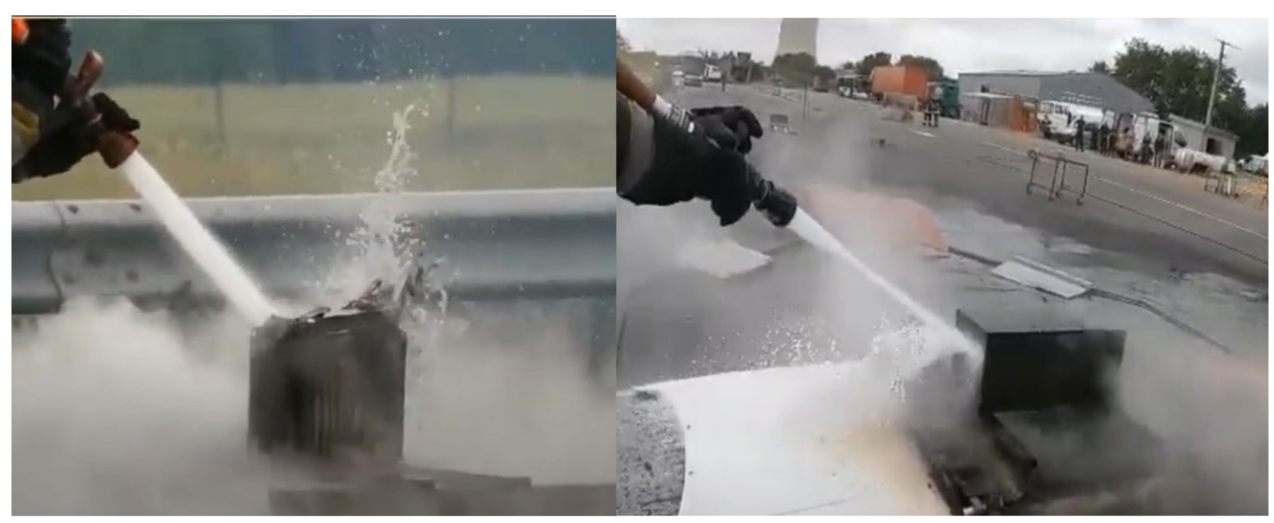

Figure 19. Exp. A.5 experiment.

In the Exp. A.6 an LTO (Prismatic) LIB pack was used. The base of this package was steel, and the periphery was covered with aluminum. Thermal runaway started to occur in the 2nd minute and 15th second from the start of heating. An intense fire was observed and also explosions with the deterioration of the prismatic cells after the thermal runaway. After the 4th minute of the beginning of heating, the water extinguishing activity was applied. The aluminum surrounding of the battery pack melted at some points and formed holes. These holes were effective in terms of extinguishing with water (Figure 20).

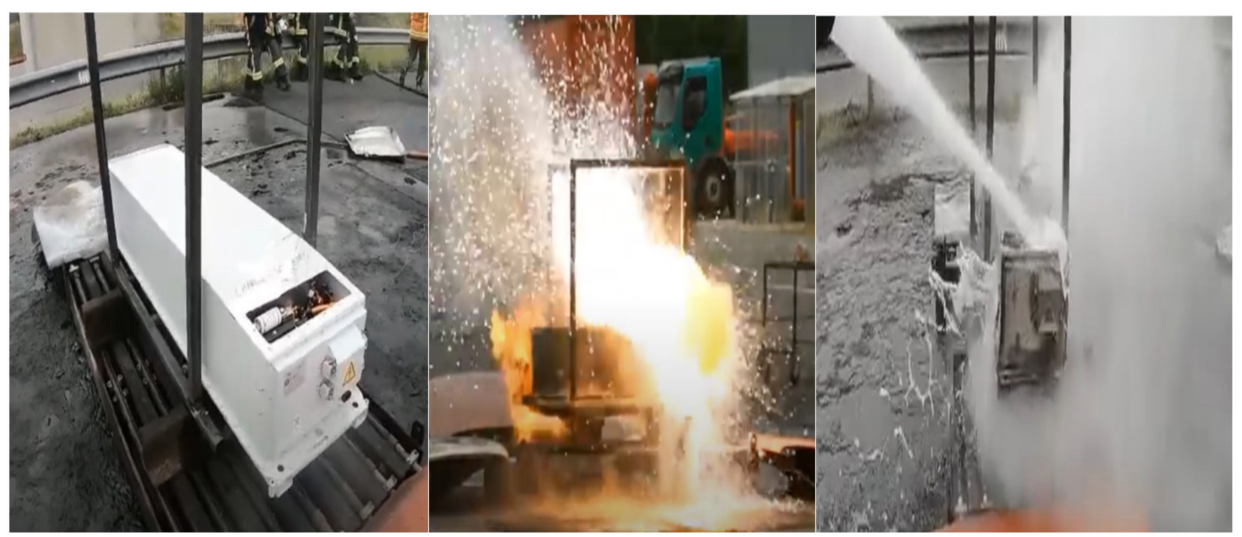

Figure 20. Exp. A.6 experiment.

In the Exp. A.6 experiments:

$\checkmark$ A large amount of water is required to extinguish the fire

$\checkmark \quad$ It has been seen that the holes and slits formed in the battery pack during the combustion, are useful for injecting water.

In the Exp. A.7 and Exp. A.8 experiments cylindrical LIBs were used. The detection of the thermal runaway phenomenon in mainly cylindrical cells is characterized by the explosion of the battery. One of the dangers of a rapidly growing technology industry is the risk involved in being intimately close to LIBs. When exposed to improper conditions, LIBs in a variety of devices have been reported to ignite, and in some cases, explode. Cylindrical 
batteries typically have safety holes to allow the internal gases to be released. These holes help reduce effects such as thermal runaway and explosion [23].

In the Exp. A.7 experiment a $13 \mathrm{~kg}, 25 \times 37 \times 18 \mathrm{~cm}$, NCA (Cylindrical), plastic case LIB was used (Figure 21). This battery is generally used in scooter-type electric vehicles. Thermal runaway started to occur $3 \mathrm{~min}$ after the start of the heating. Immediately after, extinguishing activities were started. The 4th minute of the heating, the extinguishing activity was started. Re-ignition occurred again $1 \mathrm{~h}$ after the combustion activity had fully ended. Thermal runaway occurred again 90th seconds after the second ignition.
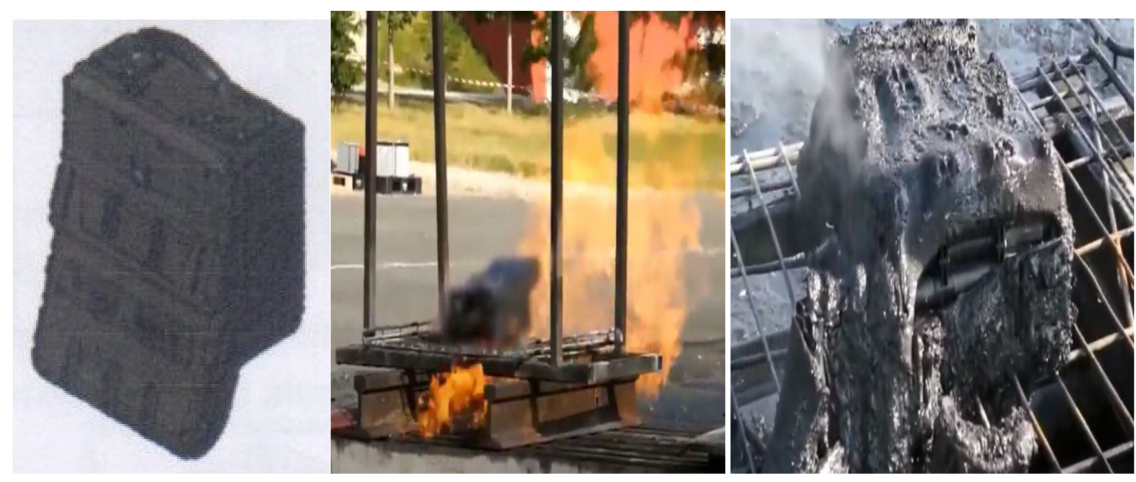

Figure 21. Exp. A.7 experiment.

In the Exp. A. 8 experiment a $20 \mathrm{~kg}, 32 \times 25 \times 21 \mathrm{~cm}$, LFP (Cylindrical), plastic case LIB was used. This battery is generally used in electric vehicles. Thermal runaway started to occur $3 \mathrm{~min}$ after the start of the heating and violent explosions started (Figure 22). The combustion was extinguished the 9 th minute of the beginning of the heating was started.

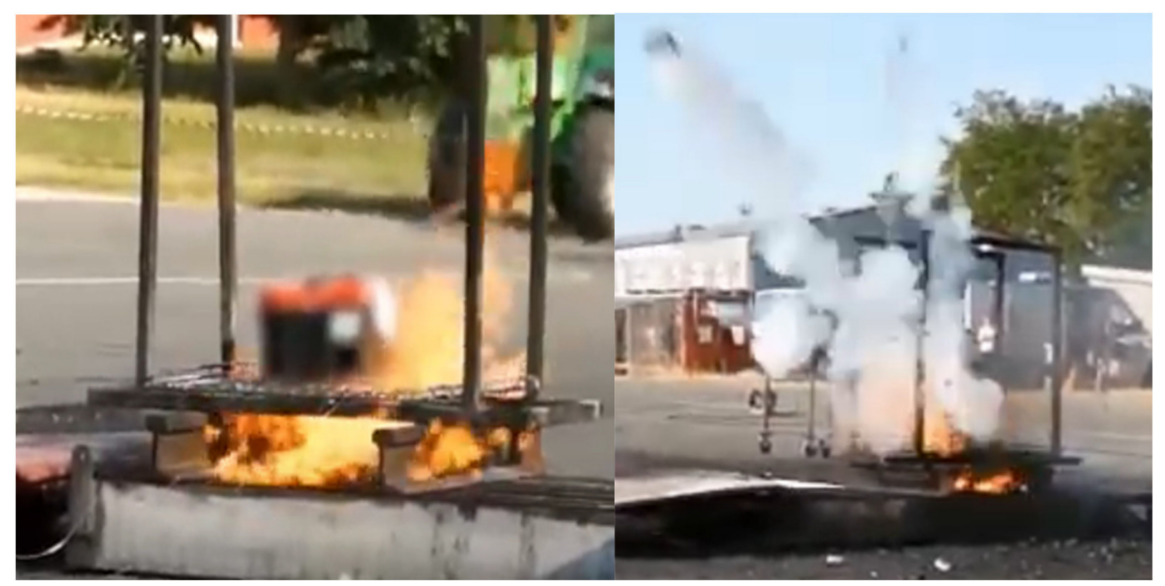

Figure 22. Exp. A.8 experiment.

In the Exp. A.7 and Exp. A.8 experiments:

$\checkmark \quad$ Plenty of water is required to extinguish the fire. While extinguishing with water, a dense white smoke was formed

$\checkmark$ During the thermal runaway of the cylindrical cells, dangerous situations such as cylindrical cell missiles have been observed.

\subsection{Exp. B.1-2}

For experiment Exp. B1 15 18,650 type $2000 \mathrm{mAh}$ LIB units were bound to each other with metal wires and placed on the $1.4 \mathrm{~kW}$ heating burner. In this experiment, only thermal runaway of lithium-ion batteries was observed (Figure 23). No extinguishing system was 
used. The results of the thermal runaway situation for the 18,650 type 2000 mAh LIBs are given in the Table 4 and Figure 24.

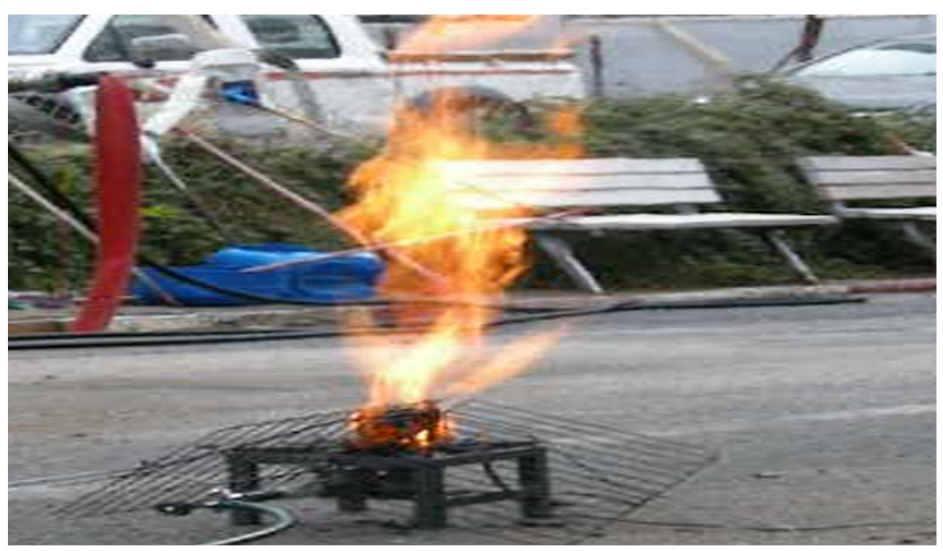

Figure 23. Explosion image during Exp. B.1.

Table 4. Exp. B.1 results.

\begin{tabular}{cc}
\hline Observations & Temperature and Time \\
\hline The time of starting to heat up & $20^{\circ} \mathrm{C}, 10: 17: 00 \mathrm{am}$ \\
Time of first gas release & $80^{\circ} \mathrm{C}, 10: 17: 50 \mathrm{am}$ \\
Time of the first explosion (Figure 23) & $90{ }^{\circ} \mathrm{C}, 10: 18: 08 \mathrm{am}$ \\
Time of the highest temperature & It was reached from $20^{\circ} \mathrm{C}$ ambient \\
& temperature to $2867^{\circ} \mathrm{C}, 10: 25: 46 \mathrm{am}$ \\
\hline
\end{tabular}

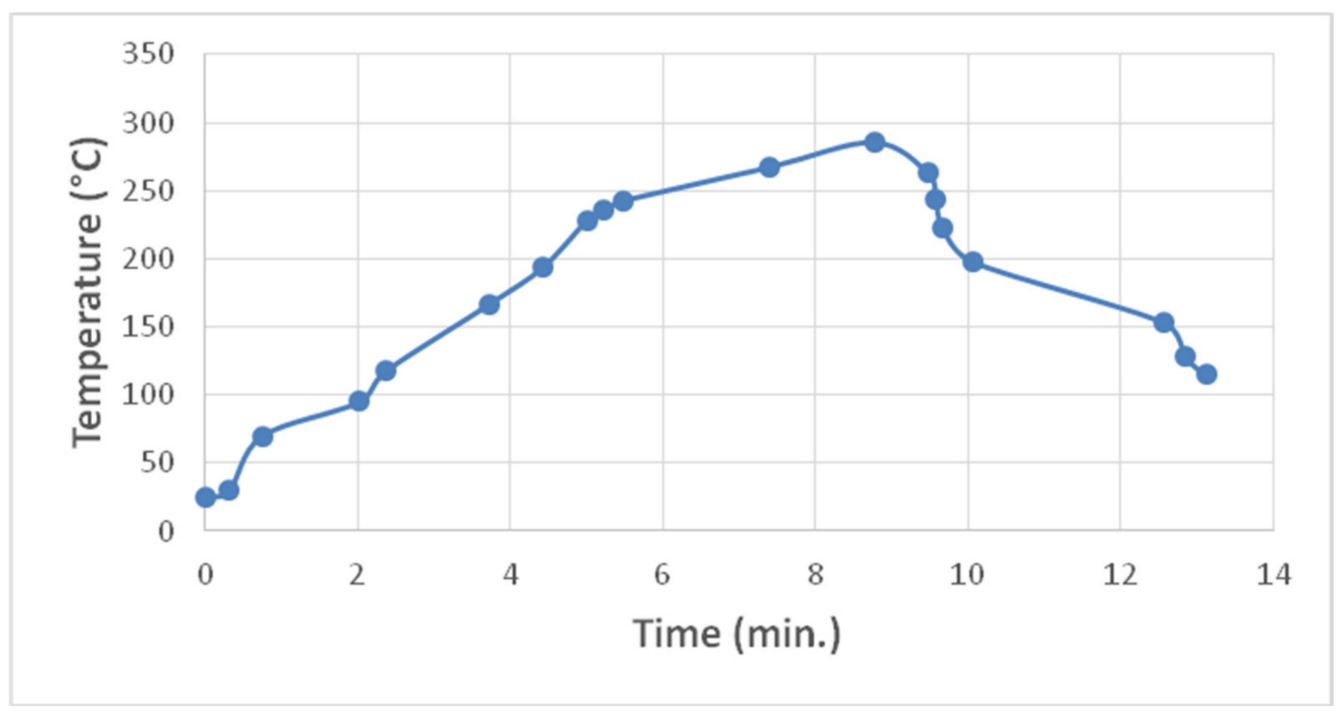

Figure 24. Exp. B.1 results (temperature/time graph).

For Exp. B.2 (Figure 25) the temperature at which AUT-BOR would be activated was determined as a set value $\left(75^{\circ} \mathrm{C}\right)$. From the moment the flame detector detected the flame, it recorded this data in the control panel as available. Afterwards, the automatic extinguishing system was activated when the temperature reached the set value of $75^{\circ} \mathrm{C}$ (Figure 14). 


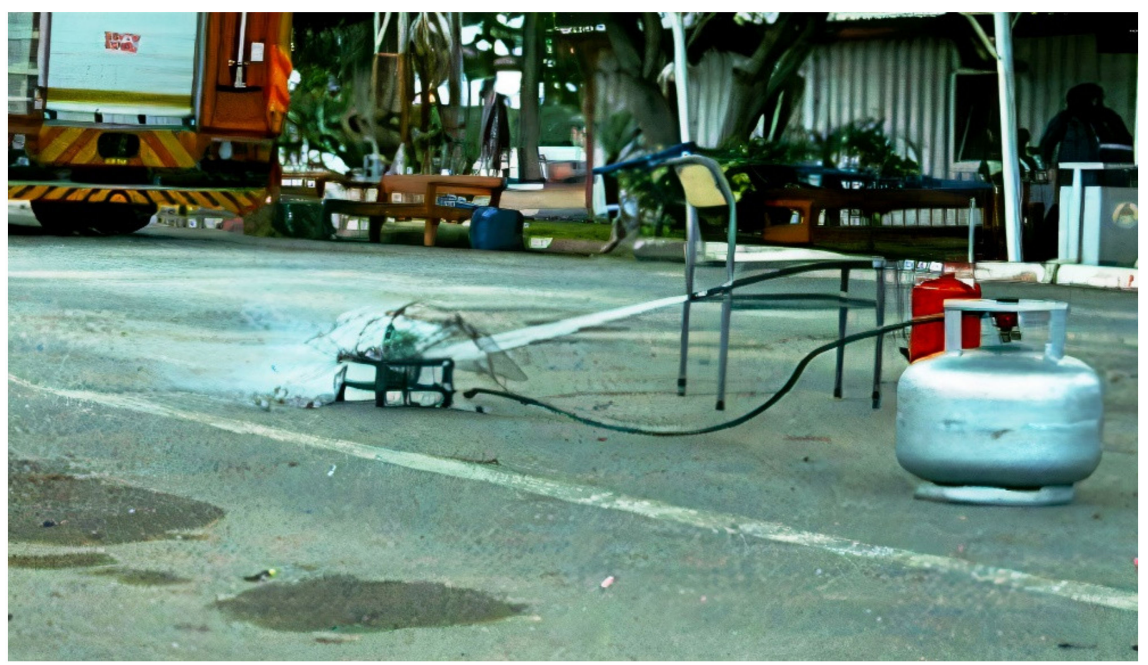

Figure 25. Exp. B.2 experiment.

The results of the thermal runaway and AUT-BOR situations are given in the Table 5 and Figure 26.

Table 5. Exp. B.2 results.

\begin{tabular}{cc}
\hline Observations & Temperature and Time \\
\hline The time of starting to heat up & $20{ }^{\circ} \mathrm{C}, 10: 47: 01$ a.m. \\
The boron-based extinguishing system was activated automatically & $75^{\circ} \mathrm{C}, 10: 47: 43$ a.m. \\
\hline
\end{tabular}

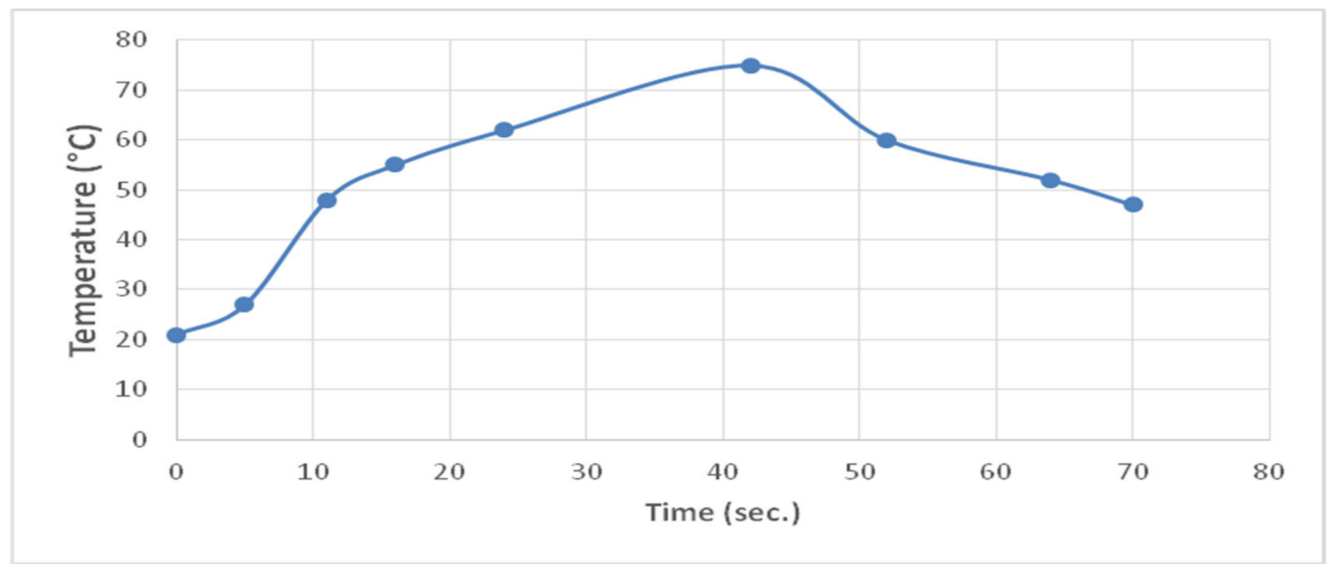

Figure 26. Exp. B.2 results (temperature/time graph).

\section{Conclusions}

Thermal runaway and fire experiments have been made with different kind of LIBs. Ten experiments have been made in this regard. Extinguishing tests were done with a manual water suppression system and an automatic boron-based fire suppression system. Fire experiments have been carried out both on cell form and on multiple modules and packs. In the Exp. A experiments, cells and batteries were placed in a system under which a propane gas burner was placed to generate $10 \mathrm{~kW}$ and $400 \mathrm{~kW}$ heat power. This propane heating was applied to other battery types in a fixed way and under the same conditions. In Exp. A experiments; for the individual cells, pure water has been seen to be an effective and convenient suppressant, due to its ability to reduce the temperature of the fire very quickly. As a result, in the event of a thermal runaway of the batteries characterized by an increased temperature, crackling, smoke, extinction is difficult (lithium-ion) or even 
impossible. Without the intervention of the fire brigade, the total combustion time of a battery can be up to $1 \mathrm{~h}$. In general, in the Exp. A experiments it was necessary to use plenty of water to completely quench the combustion. Explosion risks, such as possible missile effects, have been observed for cylindrical cells. The formation of slits and holes is important for firefighters to inject water into the battery. Gaseous outputs have been experienced with the rise of the LIBs' temperature.

Exp. A can also be achieved by applying lots of water to a cell or by submerging the battery in water. Both of these methods can suppress a LIB fire and cool the LIB, hindering exothermic reactions and preventing reignition. Water is identified as an efficient cooling and suppressing agent, but a large amount is needed for fire suppression.

The biggest advantage of cylindrical batteries in most situations is that they are very safe. Cylindrical batteries typically have safety vents to enable the release of gases that accumulate inside the battery and thus help decrease the effects of thermal runaway, including fire and explosion, with regard to the batteries used in scooters. If the internal pressure of a cylindrical lithium battery grows too high, most of the cells are designed to rupture, thus mitigating safety risks from situations like a fire or an explosion. Batteries can also cause projectile risks, which was demonstrated in this study, even though the cylindrical LIBs were equipped with a safety valve. Intense explosions of cylindrical LIBs were observed especially in both Exp. A and Exp. B.

As the battery size grows, the amount of gas released can become significant. Although fires involving LIBs can be extinguished by many methods, the effects of thermal runaway are more difficult to manage and continued cooling is required. Therefore, battery compartment construction and design should maintain an intact boundary to avoid a fire or explosion but should also include passive thermal management utilizing a combination of space separation, cooling, and zonal fire suppression within a module, and insulation between battery modules to prevent a thermal runaway reaction from spreading to adjacent modules.

The different LIB chemistries show diverse hazards. A high level of safety is achieved by adding several safety layers from the cell at a vehicle level; however, the risk for a cascading fire in a complete battery pack starting from a single cell is not yet well studied, and the knowledge about possible counteractions is thus also limited.

As a new class of fire suppressant agents, boron-based fire suppressants are effective for high temperature fires. This feature of boron-based extinguishers needs to be further improved. As seen in this study, the usage and importance of boron compounds, especially in advanced technology, is increasing daily. It is known that due to their environmentallyfriendly characteristics, boron compounds can be used in place of various other substances that are harmful to the environment. In this regard, the suppression of LIB fires can be made more environmentally-friendly by using boron compounds.

Besides suppression of LIB fires with boron, it also provides cooling. In order to make use of these characteristics of boron, more studies on this issue are needed.

Another important inference of this study, is the necessity of the automatic fire detection and suppression system for LIBs. Thermal runaway in LIBs spreads quickly. Quick detection and suppression of the fire can prevent vehicles from burning completely.

Author Contributions: Conceptualization, C.U. and K.A.; methodology, C.U. and K.A.; software, C.U. and K.A.; validation, C.U. and K.A.; formal analysis, C.U. and K.A.; investigation, C.U. and K.A.; resources, C.U. and K.A. data curation, C.U. and K.A. writing-original draft preparation, C.U. and K.A.; writing-review and editing, C.U. and K.A.; visualization, C.U. and K.A.; supervision, C.U. and K.A.; project administration, C.U. and K.A.; funding acquisition, C.U. and K.A. All authors have read and agreed to the published version of the manuscript.

Funding: This research was funded by Çukurova University Scientific Research Projects Unit, grant number FDK-2020/12753 “Development of New Generation Automatic Fire Suppression Systems for Vehicles".

Institutional Review Board Statement: Not applicable. 
Informed Consent Statement: Not applicable.

Data Availability Statement: Most of the data and the results are reported in the paper. Additional data can be requested from the corresponding author.

Conflicts of Interest: The authors declare no conflict of interest.

\section{References}

1. Boukhalfa, S.; Ravichandran, K. State of The Electric Vehicle Lithium-Ion Battery Market Report; PreScouter Publications: Chicago, IL, USA, 2019.

2. Schröder, R.; Aydemir, M.; Seliger, G. Comparatively assessing different shapes of lithium-ion battery cells. Procedia Manuf. 2017, 8, 104-111. [CrossRef]

3. Tarascon, J.M.; Armand, M. Issues and challenges facing rechargeable lithium batteries. Mater. Sustain. Energy Collect. Peer-Rev. Res. Rev. Artic. Nat. Publ. Group 2001, 414, 359-367. [CrossRef] [PubMed]

4. Ghiji, M.; Novozhilov, V.; Moinuddin, K.; Joseph, P.; Burch, I.; Suendermann, B.; Gamble, G. A review of lithium-ion battery fire suppression. Energies 2020, 13, 5117. [CrossRef]

5. Roy, P.; Srivastava, S.K. Nanostructured anode materials for lithium ion batteries. J. Mater. Chem. 2015, 3, 2454-2484. [CrossRef]

6. Russo, P.; Bari, C.D.; Mazzaro, M.; Rosa, A.D.; Morriello, I. Effective fire extinguishing systems for lithium-ion battery. Chem. Eng. Trans. 2018, 67, 727-732.

7. Sun, P.; Bisschop, R.; Niu, H. A review of battery fires in electric vehicles. Fire Technol. 2020, 56, 1-50. [CrossRef]

8. Depetro, A. Future Submarine Fire Safety Study. Master's Thesis, Victoria University, Melbourne, Australia, 2016.

9. Buckingham, J.; Hodge, C.; Hardy, T. Submarine power and propulsion-application of technology to deliver customer benefit. In Proceedings of the Undersea Defence Technology (UDT) Europe Conference, Glasgow, UK, 10-12 June 2008.

10. Spinner, N.S.; Field, C.R.; Hammond, M.H.; Williams, B.A.; Myers, K.M.; Lubrano, A.L.; Rose-Pehrsson, S.L.; Tuttle, S.G. Physical and chemical analysis of lithium-ion battery cell-to-cell failure events inside custom fire chamber. J. Power Sources 2015, 279, 713-721. [CrossRef]

11. Lamb, J.; Corendorff, J.; Steele, L.A.M.; Spangler, S.W. Failure propagation in multi-cell lithium ion batteries. J. Power Sources 2015, 283, 517-523. [CrossRef]

12. DAFO. For a Safer Environment of Electric and Hybrid Vehicles; Technical Sheet; Dafo Vehicle Fire Protection: Tyresö, Sweden, 2021.

13. Hare, G. Lithium Batteries—What's the Problem? Branz. Report: No.174; Fire and Emergency New Zealand: Wellington, New Zealand, 2019.

14. Mier, F.A.; Morales, R.; Coultas-McKenney, C.A.; Hargather, M.J.; Ostanek, J. Overcharge and thermal destructive testing of lithium metal oxide and lithium metal phosphate batteries incorporating optical diagnostics. J. Energy Storage 2017, 13, 378-386. [CrossRef]

15. Mikolajczak, C.; Kahn, M.; White, K.; Long, R.T. Lithium-Ion Batteries Hazard and Use Assessment Final Report; The Fire Protection Research Foundation: Quincy, MA, USA, 2011; p. 69.

16. McDowall, J. A guide to lithium-ion battery safety. Battcon 2014, 1, 1-23.

17. Feng, X.; Ouyang, M.; Liu, X.; Lu, L.; Xia, Y.; He, X. Thermal runaway mechanism of lithium ion battery for electric vehicles: A review. Energy Storage Mater. 2018, 10, 246-267. [CrossRef]

18. Sokmen, N.; Buyukakinci, B. The Usage of Boron/Boron Compounds in the Textile Industry and Its Situation in Turkey. In Proceedings of the CBU International Conference Proceedings, Prague, Czech Republic, 21-23 March 2018; p. 6.

19. Fireborex. Boron Based Fire Extinguisher/Coolant Material Safety Data Sheet; Demircan Fire: Izmir, Turkey, 2018.

20. Eti Maden. Sodium Tetraborate Pentahydrate Product Technical Data Sheet; General Directorate of ETI MADEN Operations: Ankara, Turkey, 2019.

21. Muenzel, V.; Hollenkamp, A.F.; Bhatt, A.I.; de Hoog, J.; Brazil, M.; Thomas, D.A.; Mareels, I. A comparative testing study of commercial 18650-format lithium-ion battery cells. J. Electrochem. Soc. 2015, 162, 1592-1600.

22. Nilsson, D.; Holmstedt, G. Kompendium Aktiva System—Detektion, Lutvdg/tvbb; Lund University: Lund, Sweden, 2007; Volume 7030 .

23. Gentilleau, M.; Delaunay, S.; Pelletier, D.; Cardou, S.; Gransagne, A.; Deparis, J. Fire Service Operational Handbook-Emergency Response on Vehicles; Departmental Fire and Rescue Service of Vienne Region Publications: Poitiers, France, 2020; Volume 7, pp. 9-10. 